\title{
Kinetics of Enzymatic Mercury Methylation at Nanomolar Concentrations Catalyzed by HgcAB
} \author{
(D) Alexander Johs ${ }^{\mathbf{a}}$ \\ aEnvironmental Sciences Division, Oak Ridge National Laboratory, Oak Ridge, Tennessee, USA \\ bBiosciences Division, Oak Ridge National Laboratory, Oak Ridge, Tennessee, USA \\ 'Department of Biological Chemistry, University of Michigan Medical School, Ann Arbor, Michigan, USA \\ dDepartment of Biochemistry, University of Missouri, Columbia, Missouri, USA
}

(D) Swapneeta S. Date, ${ }^{a}$ (D) Jerry M. Parks, ${ }^{\text {b }}$ (D) Katherine W. Rush, ${ }^{\star *}$ (D) Judy D. Wall, d (D) Stephen W. Ragsdale, ${ }^{c}$

ABSTRACT Methylmercury $(\mathrm{MeHg})$ is a potent bioaccumulative neurotoxin that is produced by certain anaerobic bacteria and archaea. Mercury $(\mathrm{Hg})$ methylation has been linked to the gene pair hgcAB, which encodes a membrane-associated corrinoid protein and a ferredoxin. Although microbial $\mathrm{Hg}$ methylation has been characterized in vivo, the cellular biochemistry and the specific roles of the gene products $\mathrm{HgcA}$ and $\mathrm{HgcB}$ in $\mathrm{Hg}$ methylation are not well understood. Here, we report the kinetics of $\mathrm{Hg}$ methylation in cell lysates of Desulfovibrio desulfuricans ND132 at nanomolar $\mathrm{Hg}$ concentrations. The enzymatic $\mathrm{Hg}$ methylation mediated by $\mathrm{HgcAB}$ is highly oxygen sensitive, irreversible, and follows Michaelis-Menten kinetics, with an apparent $K_{m}$ of $3.2 \mathrm{nM}$ and $V_{\max }$ of $19.7 \mathrm{fmol} \cdot \mathrm{min}^{-1} \cdot \mathrm{mg}^{-1}$ total protein for the substrate $\mathrm{Hg}(\mathrm{II})$. Although the abundance of $\mathrm{HgcAB}$ in the cell lysates is extremely low, $\mathrm{Hg}$ (II) was quantitatively converted to $\mathrm{MeHg}$ at subnanomolar substrate concentrations. Interestingly, increasing thiol/ $\mathrm{Hg}$ (II) ratios did not impact $\mathrm{Hg}$ methylation rates, which suggests that $\mathrm{HgcAB}$-mediated $\mathrm{Hg}$ methylation effectively competes with cellular thiols for $\mathrm{Hg}(\mathrm{II})$, consistent with the low apparent $K_{m}$. Supplementation of 5-methyltetrahydrofolate or pyruvate did not enhance MeHg production, while both ATP and a nonhydrolyzable ATP analog decreased $\mathrm{Hg}$ methylation rates in cell lysates under the experimental conditions. These studies provide insights into the biomolecular processes associated with $\mathrm{Hg}$ methylation in anaerobic bacteria.

IMPORTANCE The concentration of $\mathrm{Hg}$ in the biosphere has increased dramatically over the last century as a result of industrial activities. The microbial conversion of inorganic $\mathrm{Hg}$ to $\mathrm{MeHg}$ is a global public health concern due to bioaccumulation and biomagnification of $\mathrm{MeHg}$ in food webs. Exposure to neurotoxic $\mathrm{MeHg}$ through the consumption of fish represents a significant risk to human health and can result in neuropathies and developmental disorders. Anaerobic microbial communities in sediments and periphyton biofilms have been identified as sources of $\mathrm{MeHg}$ in aquatic systems, but the associated biomolecular mechanisms are not fully understood. In the present study, we investigate the biochemical mechanisms and kinetics of $\mathrm{MeHg}$ formation by $\mathrm{HgCAB}$ in sulfate-reducing bacteria. These findings advance our understanding of microbial MeHg production and may help inform strategies to limit the formation of $\mathrm{MeHg}$ in the environment.

KEYWORDS HgcAB, anaerobic bacteria, environmental microbiology, enzyme kinetics, mercury methylation, methylmercury

ercury $(\mathrm{Hg})$ occurs naturally in the environment and is released in part from natural sources, such as geothermal activity and volcanism. However, large quantities of $\mathrm{Hg}$ are released as a result of anthropogenic activities, such as mining
Citation Date SS, Parks JM, Rush KW, Wall JD, Ragsdale SW, Johs A. 2019. Kinetics of enzymatic mercury methylation at nanomolar concentrations catalyzed by HgcAB. Appl Environ Microbiol 85:e00438-19. https://doi .org/10.1128/AEM.00438-19.

Editor Maia Kivisaar, University of Tartu Copyright $\odot 2019$ American Society for Microbiology. All Rights Reserved.

Address correspondence to Alexander Johs, johsa@ornl.gov.

* Present address: Katherine W. Rush, Oregon Health \& Science University, Portland, Oregon, USA.

Received 21 February 2019

Accepted 20 April 2019

Accepted manuscript posted online 26 April 2019

Published 17 June 2019 
operations, coal combustion, and other industrial processes (1). In a complex global cycle, $\mathrm{Hg}$ is transformed biotically and abiotically among several major forms, including elemental $\mathrm{Hg}(0)$, mercuric $\mathrm{Hg}(\mathrm{II})$ and methylmercury $(\mathrm{MeHg})$. $\mathrm{MeHg}$ is the most prevalent organomercurial and is a potent neurotoxin (2); thus, human exposure to $\mathrm{MeHg}$ is a public health concern. MeHg bioaccumulates in the food web, and humans are exposed to this neurotoxin through their diet, particularly by consuming $\mathrm{Hg}$-contaminated fish. Certain anaerobic bacteria and archaea are capable of converting $\mathrm{Hg}$ to $\mathrm{MeHg}$. Here, we refer to these microorganisms as $\mathrm{Hg}$ methylators. The physiological role of microbial MeHg production is unclear, as $\mathrm{Hg}$ methylation apparently does not impart resistance to $\mathrm{Hg}$ toxicity (3). Interestingly, several $\mathrm{Hg}$ methylators have been shown to simultaneously methylate $\mathrm{Hg}$ and demethylate $\mathrm{MeHg}$ (4). Hg methylation has been studied in environmental samples and in pure cultures of $\mathrm{Hg}$ methylators (5-8). However, $\mathrm{Hg}$ methylation rates vary significantly with different strains, as well as in the presence of organic matter and/or thiolates $(9,10)$.

Early investigations of $\mathrm{Hg}$ methylation in cell extracts of a methanogen suggested that a methyl group could be transferred from methylcobalamin to $\mathrm{Hg}$ by both enzymatic and nonenzymatic processes (11-13). Nonenzymatic $\mathrm{Hg}$ methylation by methylcobalamin (Equation 1) is most favorable at pH $4.5(12,13)$.

$$
\mathrm{CH}_{3} \text {-cobalamin }+\mathrm{Hg}^{2+} \rightarrow \mathrm{CH}_{3} \mathrm{Hg}^{+}+\text {cobalamin }
$$

Following the identification and isolation of the sulfate-reducing bacterium Desulfovibrio desulfuricans LS as an environmentally relevant $\mathrm{Hg}$ methylator (14), a series of studies investigated associations between metabolic pathways, corrinoids, and $\mathrm{Hg}$ methylation (15-18). Based on incorporation of ${ }^{14} \mathrm{C}$ from radiolabeled precursors into $\mathrm{MeHg}$, the reductive acetyl-coenzyme A (CoA) pathway was implicated in $\mathrm{Hg}$ methylation $(15,18)$. High levels of ${ }^{14} \mathrm{C}$ incorporation into $\mathrm{MeHg}$ were observed in cultures supplemented with $\mathrm{L}-\left[3-{ }^{14} \mathrm{C}\right]$ serine and $\left[{ }^{14} \mathrm{C}\right]$ formate (18). In addition, studies with $\left[5-{ }^{14} \mathrm{CH}_{3}\right]$ tetrahydrofolate indicated that methyltetrahydrofolate $\left(\mathrm{CH}_{3}-\mathrm{H}_{4}\right.$ folate $)$ may serve as the methyl donor to form $\mathrm{MeHg}$ (17). However, enzyme activities associated with the reductive acetyl-CoA pathway were several orders of magnitude lower in $D$. desulfuricans LS than in acetogens (18). ${ }^{57} \mathrm{Co}$ labeling experiments, corrinoid extractions, and mass spectrometry identified cobalamin as the major corrinoid in $D$. desulfuricans LS (16). Additional studies implicated a 40-kDa corrinoid protein in enzymatic $\mathrm{Hg}$ methylation, but the specific protein involved was not identified or further characterized (17). As a result of these findings, it was proposed that $\mathrm{Hg}$ methylation is a two-step process involving (i) transfer of a methyl group from $\mathrm{CH}_{3}-\mathrm{H}_{4}$ folate to a corrinoid protein, followed by (ii) transfer of the methyl group from the methylcorrinoid to $\mathrm{Hg}$ (II) to form $\mathrm{MeHg}$ (17). Later studies suggested that $\mathrm{Hg}$ methylation may be independent of the acetyl-CoA pathway, as incomplete-oxidizing sulfate reducing bacteria that do not use the acetyl-CoA pathway for metabolism are still able to methylate $\mathrm{Hg}$ (19).

The genetic basis of $\mathrm{Hg}$ methylation was not well understood until recently (20). The hgcAB gene pair was shown to be required for $\mathrm{Hg}$ methylation in the sulfate-reducing bacterium Desulfovibrio desulfuricans ND132 and in the iron-reducing bacterium Geobacter sulfurreducens PCA (20). Deletion of either gene resulted in a complete loss of $\mathrm{Hg}$ methylation activity. To date, all strains of bacteria and archaea with hgcAB genes that have been assayed for $\mathrm{Hg}$ methylation are capable of producing $\mathrm{MeHg}(3,6)$.

Based on sequence analysis and homology modeling it was predicted that hgcA encodes a protein consisting of a corrinoid-binding domain (CBD) facing the cytosol and a transmembrane domain (TMD) anchored in the cytoplasmic membrane (Fig. 1A) (20). The CBD of HgcA is homologous to the CBD of the corrinoid iron-sulfur protein (CFeSP) from the reductive acetyl-CoA (Wood-Ljungdahl) pathway of carbon fixation (20), but the TMD has no detectable sequence similarity to that of any known protein (20). The CBD of HgcA contains a strictly conserved Cys residue (C93) that is critical for $\mathrm{Hg}$ methylation activity in vivo (21). The gene $h g c B$ almost always appears immediately 

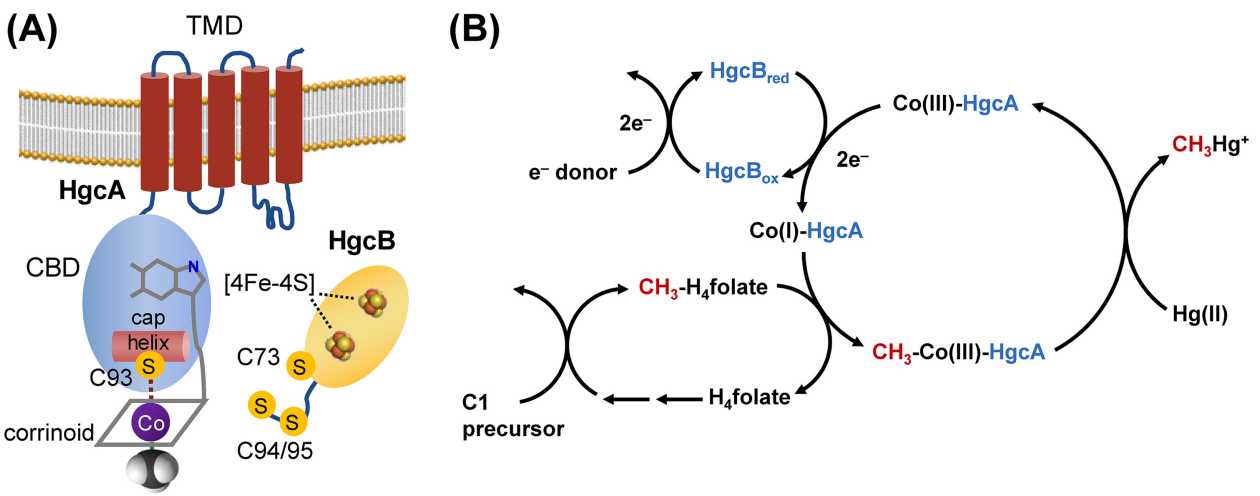

FIG 1 Structural features and proposed mechanism of HgcAB-mediated Hg methylation. (A) Cartoon representation of sequence-based structural models of $\mathrm{HgcA}$ and $\mathrm{HgcB}$. Key components and features are labeled as follows: TMD, transmembrane domain; $C B D$, corrinoid-binding domain; [4Fe-4S], iron-sulfur cluster; $C$, cysteine). (B) Proposed roles of $\mathrm{HgcA}$ and $\mathrm{HgcB}$ in $\mathrm{Hg}$ methylation (C1 precursor, one-carbon compound; $\mathrm{Co}(\mathrm{I}) /(\mathrm{III})$, cobalt center of a corrinoid cofactor and its oxidation state; $\mathrm{H}_{4}$ folate, tetrahydrofolate; $\mathrm{CH}_{3}-\mathrm{H}_{4}$ folate, 5-methyltetrahydrofolate; $\mathrm{Hg}(\mathrm{II})$, mercuric mercury; $\mathrm{CH}_{3} \mathrm{Hg}^{+}$, methylmercury.

downstream of $h g c A$ and encodes a ferredoxin with two [4Fe-4S] cluster-binding motifs (20). $\mathrm{HgcB}$ has a unique architecture among ferredoxins, consisting of two [4Fe-4S] cluster-binding motifs $\left(\mathrm{CX}_{2} \mathrm{CX}_{2} \mathrm{CX} \mathrm{X}_{3} \mathrm{CP}\right)$, an additional strictly conserved Cys residue (C73), and a pair of conserved cysteines at the $C$ terminus (C94 and C95) (Fig. 1A) (20, 21). It is not known whether $\mathrm{HgcA}$ and $\mathrm{HgcB}$ form a multiprotein complex. However, we refer here to these proteins collectively as $\mathrm{HgcAB}$ to emphasize that both are required for $\mathrm{Hg}$ methylation.

A general mechanism for $\mathrm{Hg}$ methylation by $\mathrm{HgcAB}$ is shown (Fig. 1B). The reaction cycle begins with $\mathrm{HgcB}$ providing low-potential electrons to the oxidized corrinoid cofactor of HgcA to generate the supernucleophilic $\mathrm{Co}(\mathrm{I})$ state. The $\mathrm{Co}(\mathrm{I})$-corrinoid then accepts a methyl group from a methyl donor, such as $\mathrm{CH}_{3}-\mathrm{H}_{4}$ folate, to form a $\mathrm{CH}_{3}$ $\mathrm{Co}(\mathrm{III})$-corrinoid. The methylcorrinoid then transfers its methyl group to a $\mathrm{Hg}$ (II) substrate, either directly or through a ligand exchange reaction $(22,23)$, to form $\mathrm{CH}_{3} \mathrm{Hg}^{+}$. After methyl transfer, the corrinoid is in an oxidized state. Thus, every turnover cycle requires low-potential electrons, donated by $\mathrm{HgcB}$, to reduce the corrinoid to the $\mathrm{Co}(\mathrm{I})$ state. How the $\mathrm{Hg}(\mathrm{II})$ substrate enters cells and interacts with $\mathrm{HgcAB}$ is currently unknown, but uptake and transport of $\mathrm{Hg}(\mathrm{II})$ into the cytoplasm are essential and may limit methylation rates observed in vivo $(24,25)$.

To evaluate the kinetics of $\mathrm{Hg}$ methylation mediated by $\mathrm{HgcA}$ and $\mathrm{HgcB}$ independent of transport processes, we performed $\mathrm{Hg}$ methylation assays in cell lysates of $D$. desulfuricans ND132. ND132 is a sulfate-reducing bacterium that is often used as a model organism for studying $\mathrm{Hg}$ methylation due to robust $\mathrm{Hg}$ methylation by ND132 and its similarity to $D$. desulfuricans $\operatorname{LS}(3,26)$. The present study using ND132 builds on the foundation of earlier studies conducted with the strain $D$. desulfuricans LS, which was not sequenced and is considered lost (15-18). Owing to advances in MeHg analysis, we perform experiments at much lower and more environmentally relevant levels of $\mathrm{Hg}$ ( 0.5 to $60 \mathrm{nM}$ compared to the 0.5 to $8 \mathrm{mM}$ ) previously used for studies with $D$. desulfuricans LS (17). We follow Hg methylation rates in ND132 cell lysates over time and study the effects of $\mathrm{pH}$, temperature, and total protein concentration. We determine initial rates of $\mathrm{Hg}$ methylation in cell lysates as a function of $\mathrm{Hg}$ (II) concentration and calculate apparent kinetic parameters $\left(K_{m}\right.$ and $\left.V_{\text {max }}\right)$ for the ND132 wild type (WT) and compare results to those from an $h g c A B$ deletion mutant $(\triangle h g c A B)$. Furthermore, we evaluate the contributions of enzymatic $\mathrm{Hg}$ methylation and nonenzymatic $\mathrm{Hg}$ methylation, as well as whether the $\mathrm{Hg}$ methylation reaction is reversible or a separate $\mathrm{MeHg}$ demethylation pathway exists in ND132. We also conduct a set of targeted experiments to gain insights into aspects of the proposed mechanism of $\mathrm{Hg}$ methylation by $\mathrm{HgcA}$ and $\mathrm{HgcB}$. Specifically, we investigate the sensitivity of $\mathrm{Hg}$ methylation 

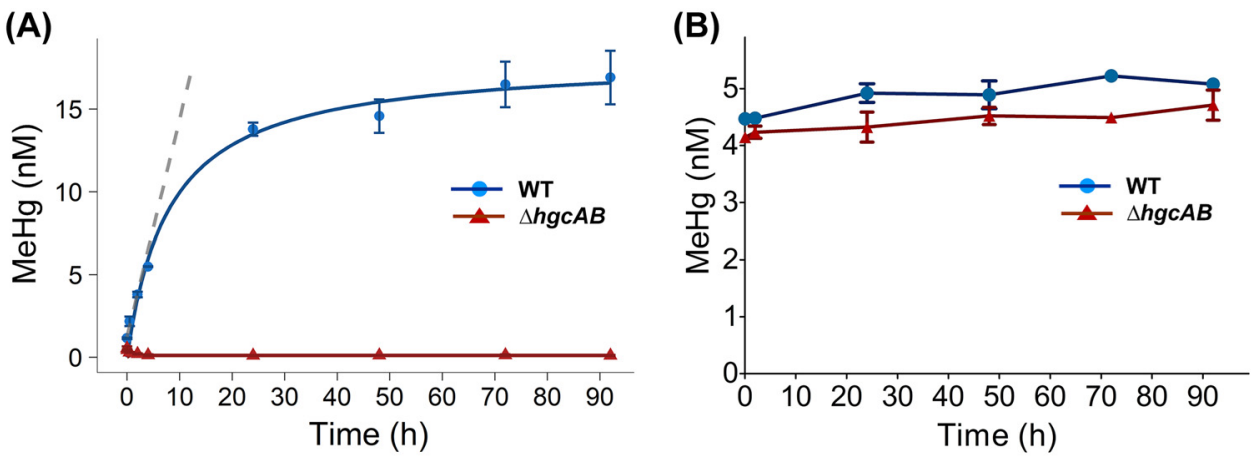

FIG 2 Time dependence of $\mathrm{Hg}$ methylation and $\mathrm{MeHg}$ demethylation in ND132. (A) Hg methylation in cell lysates of ND132 WT (blue) and $\triangle$ hgcAB (red) $(1.5 \mathrm{mg} / \mathrm{ml}$ total protein concentration) under strictly anaerobic conditions at $32^{\circ} \mathrm{C}$ in the presence of $30 \mathrm{nM} \mathrm{Hg}(\mathrm{II})$. The blue line shows a nonlinear fit of the concentration data and the gray dashed line shows a linear fit $\left(R^{2}=0.98\right)$ for time points between 0 and $2 \mathrm{~h}$ to determine initial rates. (B) MeHg concentrations in ND132 cell lysates of WT (blue) and $\triangle h g c A B$ (red) as a function of time under a similar experimental setup as that in panel A but with $5 \mathrm{nM} \mathrm{MeHg}$ as the substrate. Error bars represent standard deviation between duplicate sets of samples $(n=2)$.

to oxygen exposure, evaluate a potential role of ATP in $\mathrm{Hg}$ methylation and determine the effect of supplementation of the cellular metabolites $\mathrm{CH}_{3}-\mathrm{H}_{4}$ folate and pyruvate, which are proposed methyl and electron donors, respectively.

\section{RESULTS}

Time dependence of $\mathbf{H g}$ methylation and $\mathbf{M e H g}$ demethylation. The time course for the conversion of $\mathrm{Hg}$ (II) to MeHg in cell lysates of ND132 WT and $\triangle h g c A B$ was determined over a period of up to $92 \mathrm{~h}$. The levels of MeHg produced in WT cell lysates increased at a rate of $1.31 \pm 0.14 \mathrm{nM} / \mathrm{h}$ within the first $2 \mathrm{~h}$, decreasing over time and plateauing between 24 and $92 \mathrm{~h}$ (Fig. 2A). At the 92-h time point, $56.4 \%$ of the added $\mathrm{Hg}(\mathrm{II})$ was converted to MeHg. No significant MeHg production was observed in $\triangle \mathrm{hgc} A B$ cell lysates over the course of the experiment. MeHg levels in $\triangle h g c A B$ cell lysates were $<0.5 \%$ of $\mathrm{MeHg}$ in WT cell lysates at $92 \mathrm{~h}$, confirming that $\mathrm{Hg}$ methylation in ND132 cell lysates is strictly an $\mathrm{HgcAB}$-dependent process. In addition, the lack of significant $\mathrm{MeHg}$ production in $\triangle h g c A B$ cell lysates indicates that nonenzymatic methylation mediated by methylcorrinoids, either free (Equation 1) or associated with other proteins, did not contribute significantly to $\mathrm{MeHg}$ formation in the cell lysates. Initial rates of $\mathrm{Hg}$ methylation measured over the first $2 \mathrm{~h}$ after $\mathrm{Hg}$ (II) addition were used for subsequent experiments.

To determine whether a fraction of $\mathrm{Hg}$ was reduced to $\mathrm{Hg}(0)$ over the course of the experiment and to close the $\mathrm{Hg}$ mass balance, we also measured the total $\mathrm{Hg}(\mathrm{THg})$ for every time point. No significant changes in THg levels were observed, eliminating the possibility that $\mathrm{Hg}$ was lost through reduction to $\mathrm{Hg}(0)$ over the course of the experiment (Fig. S1).

To determine whether MeHg is demethylated in ND132 cell lysates, we incubated WT cell lysates with $5 \mathrm{nM} \mathrm{MeHg}$ and measured MeHg levels over time up to $92 \mathrm{~h}$. Considering that demethylation may be independent of $\mathrm{HgcAB}$, we compared the demethylation of MeHg in cell lysates of both ND132 WT and the $\triangle$ hgcAB mutant. No demethylation was observed for either strain (Fig. 2B).

$\mathbf{p H}$, temperature, and total protein concentration dependence of $\mathrm{Hg}$ methylation. To provide further evidence that $\mathrm{Hg}$ methylation in ND132 cell lysates is an enzymatic process, we determined $\mathrm{Hg}$ methylation rates as a function of $\mathrm{pH}$, temperature, and total protein concentration. The rate of $\mathrm{MeHg}$ production in WT cell lysates increased by a factor of 6.5 between $\mathrm{pH} 4.0(0.32 \pm 0.06 \mathrm{nM} / \mathrm{h})$ and $\mathrm{pH}$ $8.0(2.12 \pm 0.03 \mathrm{nM} / \mathrm{h}$ ) (Fig. 3A). Hg methylation rates in WT cell lysates varied by an order of magnitude between $4^{\circ} \mathrm{C}(0.22 \pm 0.00 \mathrm{nM} / \mathrm{h})$ and $32^{\circ} \mathrm{C}(1.91 \pm 0.12 \mathrm{nM} / \mathrm{h})$, and between $32^{\circ} \mathrm{C}$ and $50^{\circ} \mathrm{C}(0.14 \pm 0.01 \mathrm{nM} / \mathrm{h})$, with a fairly narrow optimum centered around $32^{\circ} \mathrm{C}$ (Fig. 3B). 

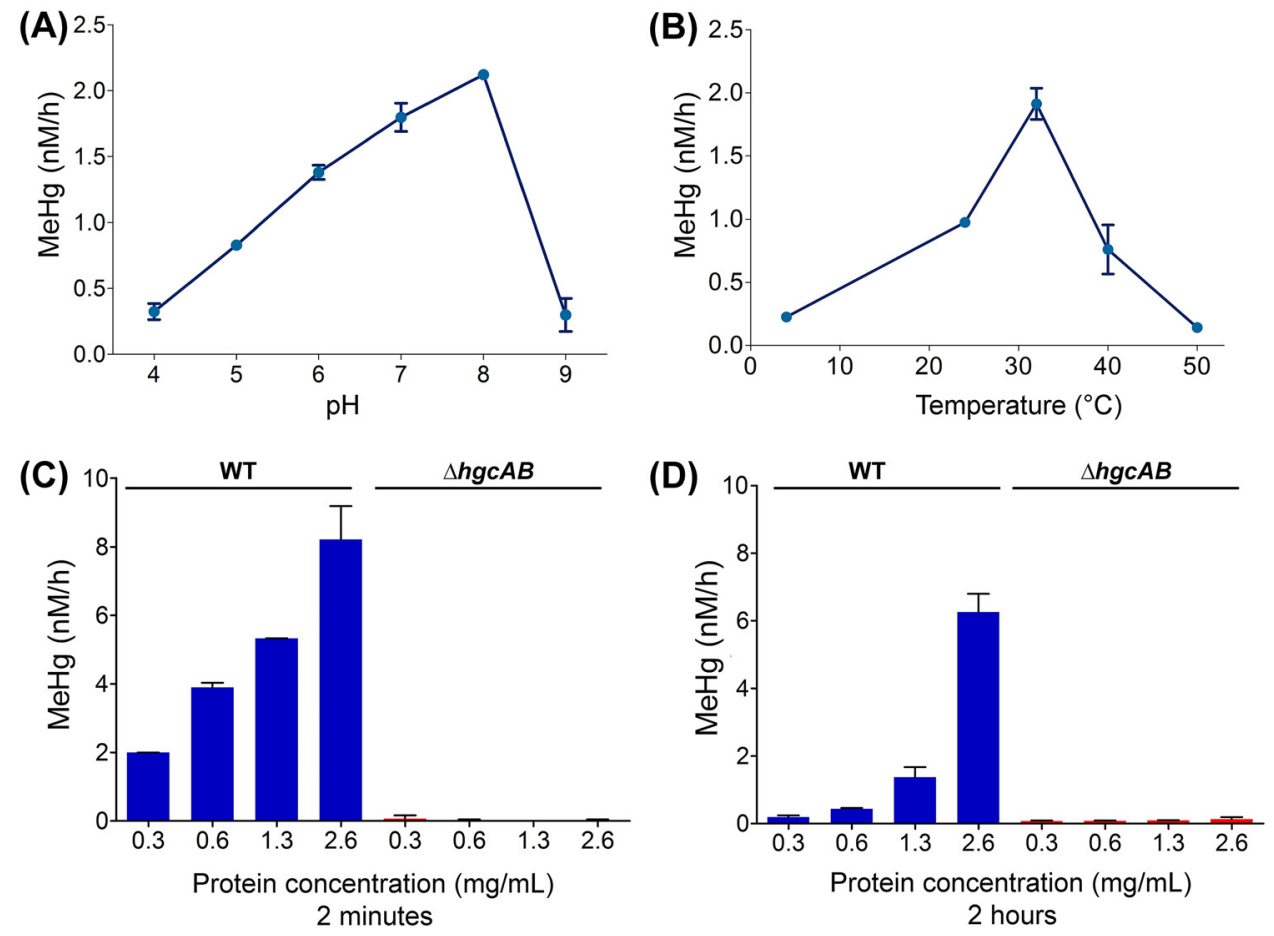

FIG 3 Dependence of $\mathrm{Hg}$ methylation rates on $\mathrm{pH}$, temperature, and total protein concentration. Hg methylation rates in cell lysates of ND132 WT measured as a function of (A) $\mathrm{pH}(4,5,6,7,8$, and 9), (B) temperature $(4,24$ [room temperature], 32,40 , and $50^{\circ} \mathrm{C}$ ), and $(C$ and $D)$ total protein concentration. Samples were incubated with $30 \mathrm{nM}$ $\mathrm{Hg}(\mathrm{II})$ and harvested for $\mathrm{MeHg}$ analysis at $2 \mathrm{~h}$, except in panel $\mathrm{C}$, where samples were harvested at $2 \mathrm{~min}$ after $\mathrm{Hg}$ (II) addition. $\mathrm{pH} 7,32^{\circ} \mathrm{C}$, and strictly anaerobic conditions correspond to standard experimental conditions. Error bars represent standard deviation between duplicate sets of samples $(n=2)$.

To investigate the effect of total protein concentration on the rate of $\mathrm{Hg}$ methylation in cell lysates, we measured MeHg production rates at $2 \mathrm{~min}$ (Fig. 3C) and $2 \mathrm{~h}$ (Fig. 3D) over a range of up to $\sim 8$ times the initial total protein concentration $(0.3 \mathrm{mg} / \mathrm{ml}$ to $2.6 \mathrm{mg} / \mathrm{ml}$ ). The highest total protein concentration achievable is limited by the volume of buffer required to resuspend cell pellets prior to cell lysis. As expected, the rate of $\mathrm{MeHg}$ formation increased with increasing concentrations of total protein. Although the initial rates determined within 2 min of the addition of $\mathrm{Hg}$ (II) were higher and increased linearly in response to total protein concentration, methylation rates determined at $2 \mathrm{~h}$ increased exponentially with increasing total protein concentrations.

Enzyme kinetics of HgcAB-mediated Hg methylation. To examine the effects of increasing substrate concentrations on the rate of $\mathrm{MeHg}$ production, we incubated ND132 cell lysates $\left(1.5 \mathrm{mg} / \mathrm{ml}\right.$ total protein concentration) with $\mathrm{Hg}$ (II) (added as $\mathrm{HgCl}_{2}$ ) as a substrate at concentrations ranging from $0.5 \mathrm{nM}$ to $60 \mathrm{nM}$. $\triangle$ hgcAB cell lysates were used as a negative control. Initial MeHg formation rates followed Michaelis-Menten kinetics with a maximum rate $V_{\text {max }}$ of $19.7( \pm 0.35) \mathrm{fmol} \cdot \mathrm{mg}$ total protein ${ }^{-1} \cdot \mathrm{min}^{-1}$ and a $K_{m}$ of $3.2 \mathrm{nM}$ ( \pm 0.26) for $\mathrm{Hg}$ (II) (Fig. 4A). $\mathrm{CH}_{3}-\mathrm{H}_{4}$ folate is the presumed methyl donor for MeHg. As described in the following section, $\mathrm{CH}_{3}-\mathrm{H}_{4}$ folate levels were not rate limiting under the current experimental conditions. Furthermore, the addition of dithiothreitol (DTT) at concentrations above $2 \mathrm{mM}$ did not affect the observed $\mathrm{Hg}$ methylation rates (Fig. S2). At low concentrations of $\mathrm{Hg}(\mathrm{II}), 0.5 \mathrm{nM}$ and $1 \mathrm{nM}$, nearly $100 \%$ of the added $\mathrm{Hg}$ (II) was converted to MeHg (Fig. 4B).

Reverse transcription-PCR (RT-PCR) data from ND132 (20) and proteomics studies in ND132 (27) and G. sulfurreducens PCA (28) indicated that the abundance of HgCA and $\mathrm{HgcB}$ in $\mathrm{Hg}$ methylators is extremely low. Owing to the low abundance and resultant difficulties in determining accurate concentrations of $\mathrm{HgcA}$ and $\mathrm{HgcB}$ in the cell lysates, we used the obtained kinetic parameters to estimate turnover numbers $\left(k_{\text {cat }}\right)$, catalytic 
(A)

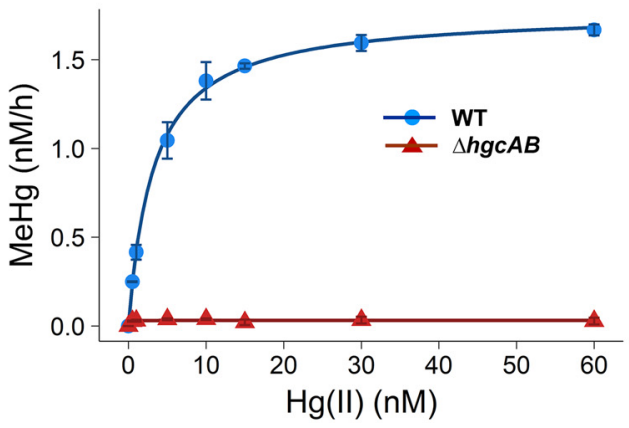

(B)

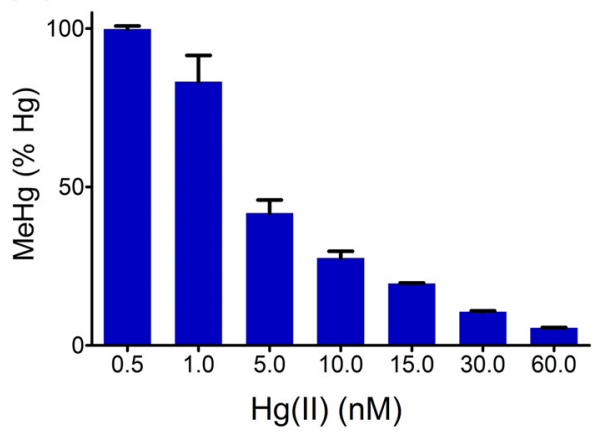

FIG 4 Dependence of $\mathrm{Hg}$ methylation rates on $\mathrm{Hg}$ substrate concentration. (A) Initial rates of Hg methylation in ND132 cell lysates $(1.5 \mathrm{mg} / \mathrm{ml}$ total protein) in response to increasing concentrations of added $\mathrm{Hg}$ (II) from $0.5 \mathrm{nM}$ to $60 \mathrm{nM}$ at $32^{\circ} \mathrm{C}$ for $2 \mathrm{~h}$ under strictly anaerobic conditions for WT (blue circles) and $\triangle$ hgc $A B$ strains (red triangles). $\mathrm{Hg}$ methylation rates in WT cell lysates were fitted to the Michaelis-Menten equation with a $V_{\max }$ of $1.77 \pm 0.03 \mathrm{nM} / \mathrm{h}$ and $K_{m}$ of $3.2 \pm 0.26 \mathrm{nM}$ (blue line). (B) Percentage of $\mathrm{Hg}$ (II) converted to MeHg within $2 \mathrm{~h}$ as a function of initial $\mathrm{Hg}(\mathrm{II})$ concentration. Error bars represent standard deviation between duplicate set of samples $(n=2)$.

efficiencies $\left(k_{\text {cat }} / K_{m}\right)$, and free energies of activation based on transition state theory $(29,30)$ for a range of enzyme concentrations expressed as a fraction of total cellular protein concentration (Table 1, Fig. S3). It should be noted that these values are calculated solely for the purpose of gaining further insights into the functioning of $\mathrm{HgcAB}$ based on estimated kinetic parameters. Additionally, since the value for $V_{\max }$ reported here is normalized to the total protein in the lysates, the $V_{\max }$ of the pure enzyme is expected to be higher. Nevertheless, the value of $K_{m}$, which is independent of the enzyme concentration, suggests that $\mathrm{HgcA}$ and $\mathrm{HgcB}$ readily bind $\mathrm{Hg}$ (II) at very low concentrations.

Effect of oxygen and cellular metabolites on $\mathbf{H g}$ methylation. Based on the current mechanistic hypothesis, each $\mathrm{MeHg}$ formation turnover cycle requires the transfer of low-potential electrons to reduce the corrinoid of $\mathrm{HgcA}$ to the $\mathrm{Co}(\mathrm{I})$ state to accept a methyl group from a methyl donor (Fig. 1B). The presence of oxygen would raise the redox potential in solution and rapidly oxidize any $\mathrm{Co}(\mathrm{I})$ due to the low midpoint potential of the $\mathrm{Co}(\mathrm{I}) / \mathrm{Co}(\mathrm{II})$ couple $(31,32)$. Therefore, corrinoid-dependent methyl transfer reactions are highly redox sensitive. Exposure to oxygen would interrupt the transfer of methyl groups to the corrinoid and inhibit MeHg formation. To test the effect of oxygen on $\mathrm{Hg}$ methylation, MeHg production in ND132 cell lysates was measured under both aerobic (exposed to ambient oxygen levels) and anaerobic conditions (standard experimental conditions in a glove box under $\mathrm{N}_{2}$ and $<0.6 \mathrm{ppm}$ $\mathrm{O}_{2}$ ). MeHg formation was inhibited by $95 \%(P<0.001)$ in the presence of ambient oxygen (Fig. 5A). As expected, no effect of ambient oxygen on $\mathrm{MeHg}$ formation was observed in the $\triangle h g c A B$ cell lysates. Thus, the observed oxygen sensitivity of HgcABmediated $\mathrm{Hg}$ methylation in cell lysates of WT ND132 is consistent with the proposed requirement for low-potential electrons (i.e., $<-450 \mathrm{mV}$ ) for the corrinoid in $\mathrm{HgcA}$ to achieve the $\mathrm{Co}(\mathrm{I})$ state $(31,32)$. Additionally, the presence of oxygen may also affect the oxidation state of the two [4Fe-4S] clusters in $\mathrm{HgcB}$.

TABLE 1 Turnover numbers, catalytic efficiencies, and activation free energies of enzymatic $\mathrm{Hg}$ methylation for a range of postulated enzyme concentrations

\begin{tabular}{llll}
\hline [E] $^{a}(\%$ of total protein) & $\boldsymbol{k}_{\mathrm{cat}}\left(\mathrm{s}^{-1}\right)$ & $\boldsymbol{k}_{\mathrm{cat}} / K_{\boldsymbol{m}}\left(\mathrm{M}^{-1} \cdot \mathrm{s}^{-1}\right)$ & $\Delta \boldsymbol{G}^{\ddagger b}\left(\mathrm{kcal} \cdot \mathrm{mol}^{-1}\right)$ \\
\hline 0.1 & $1.2 \times 10^{-5}$ & $4 \times 10^{3}$ & 24.1 \\
0.01 & $1.2 \times 10^{-4}$ & $4 \times 10^{4}$ & 22.8 \\
0.001 & $1.2 \times 10^{-3}$ & $4 \times 10^{5}$ & 21.4 \\
0.0001 & $1.2 \times 10^{-2}$ & $4 \times 10^{6}$ & 20.1 \\
\hline
\end{tabular}

$a[E]$, concentration of $\mathrm{HgcA}$, expressed as a fraction of total cell protein.

${ }^{b} \Delta G^{\ddagger}$, activation free energy. 
(A)

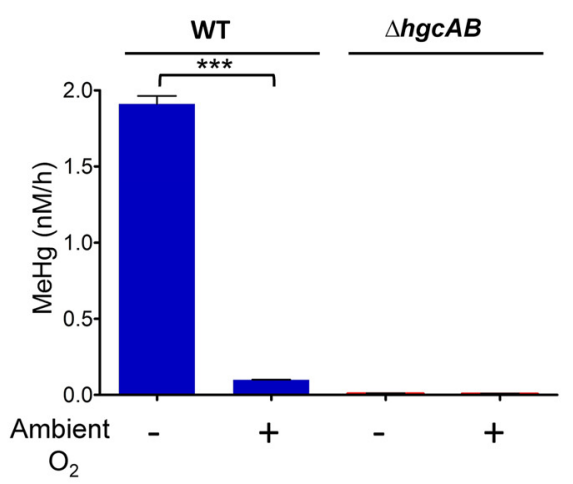

(C)

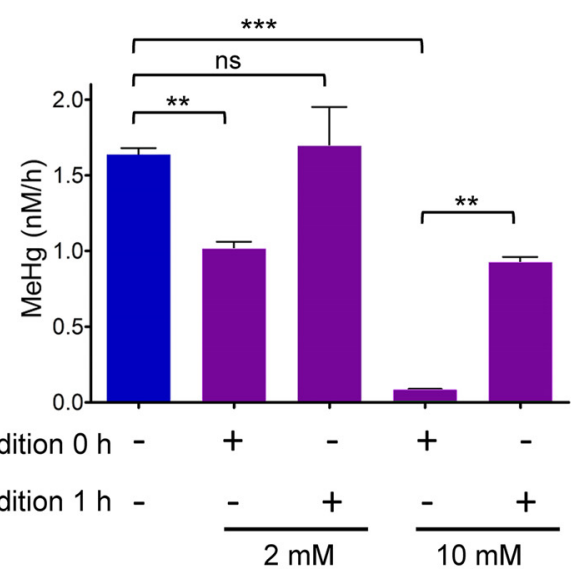

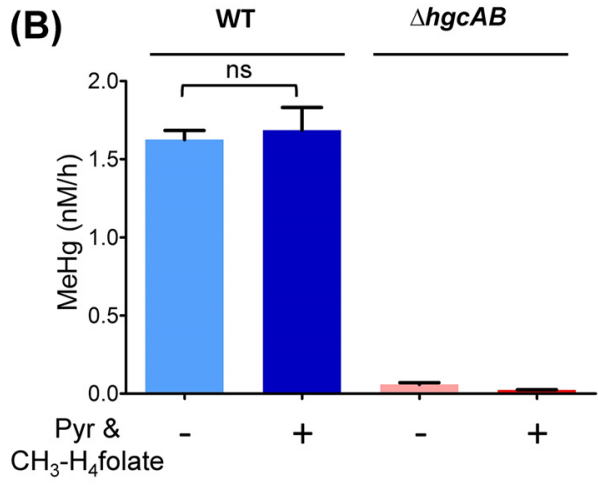

(D)

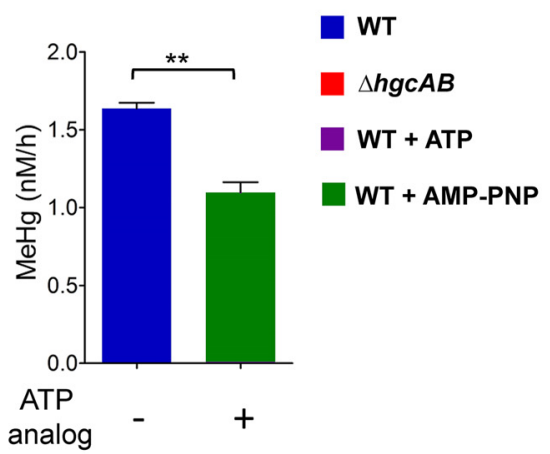

FIG 5 Effect of ambient oxygen and key cellular metabolites on $\mathrm{Hg}$ methylation. (A) Hg methylation rates in WT ND132 cell lysates and $\triangle h g c A B$ under aerobic (exposed to ambient oxygen) and anaerobic conditions ( $\mathrm{N}_{2}$ environment, $<0.6 \mathrm{ppm}$ $\mathrm{O}_{2}$ ). (B) $\mathrm{Hg}$ methylation rates in WT ND132 cell lysates and $\triangle h g c A B$ under unamended conditions compared to the Hg methylation rates for samples amended with $16.8 \mu \mathrm{M} \mathrm{CH}_{3}-\mathrm{H}_{4}$ folate and $10 \mathrm{mM}$ pyruvate (Pyr). (C) Effect of $2 \mathrm{mM}$ ATP and $10 \mathrm{mM}$ ATP on the concentration of $\mathrm{MeHg}$ produced at $2 \mathrm{~h}$ in the presence of $30 \mathrm{nM} \mathrm{Hg}(\mathrm{II})$ compared to that in the unamended sample. ATP was supplemented before the addition of $\mathrm{Hg}$ (II) (ATP addition at $0 \mathrm{~h}$ ) or $1 \mathrm{~h}$ after the addition of $\mathrm{Hg}$ (II) (ATP addition at $1 \mathrm{~h}$ ). (D) Effect of $5 \mathrm{mM}$ nonhydrolyzable ATP analog AMP-PNP on MeHg production compared to the unamended sample. Data were analyzed with a two-sample $t$ test. Not significant (ns), $P>0.05 ;{ }^{* *}, P \leq 0.01 ;{ }^{* * *}$, $P \leq 0.001$. Error bars represent the standard deviation between duplicates $(n=2)$.

$\mathrm{CH}_{3}-\mathrm{H}_{4}$ folate was previously proposed as a potential methyl donor required for the formation of $\mathrm{MeHg}$. Furthermore, no $\mathrm{Hg}$ methylation was detected in cell lysates of $D$. desulfuricans LS without the addition of $10 \mathrm{mM}$ pyruvate, in which pyruvate was proposed to play a role in the generation of reductant such as reduced ferredoxin (15, $17,18)$. To determine whether the exogenous addition of $16.8 \mu \mathrm{M} \mathrm{CH}-\mathrm{H}_{4}$ folate and $10 \mathrm{mM}$ pyruvate, as used in previous studies, leads to increased $\mathrm{Hg}$ methylation, we compared the $\mathrm{Hg}$ methylation rates under our standard experimental conditions (i.e., unamended) to that of samples amended with pyruvate and $\mathrm{CH}_{3}-\mathrm{H}_{4}$ folate. No significant changes in the rate of $\mathrm{MeHg}$ formation were observed in response to the combined addition of $16.8 \mu \mathrm{M} \mathrm{CH}_{3}-\mathrm{H}_{4}$ folate and $10 \mathrm{mM}$ pyruvate $(P>0.05)$ (Fig. 5B). Because the $\mathrm{Hg}(\mathrm{II})$ concentration used for the current experiments ( $30 \mathrm{nM})$ is much lower than the levels used for assays with $D$. desulfuricans $L S(0.7 \mathrm{mM})$, we propose that the availability of pyruvate and $\mathrm{CH}_{3}-\mathrm{H}_{4}$ folate were not limiting factors during $\mathrm{MeHg}$ formation under our experimental conditions. In addition, involvement of a physiological methyl donor other than $\mathrm{CH}_{3}-\mathrm{H}_{4}$ folate cannot be ruled out.

Previous studies have proposed a role for ATP driving the uptake or methylation of $\mathrm{Hg}$ (24). To determine whether $\mathrm{Hg}$ methylation in cell lysates is ATP-dependent, we measured the effect of exogenously added ATP on MeHg formation independent of uptake processes. ATP was added to cell lysates at a concentration of $2 \mathrm{mM}$, which is close to the average physiological ATP concentration determined for Escherichia coli 
cells (33), and in excess, $10 \mathrm{mM}$. ATP was added at $0 \mathrm{~h}$, i.e., before adding $\mathrm{Hg}$. In a separate set of samples, ATP was supplemented $1 \mathrm{~h}$ after $\mathrm{Hg}$ was added (ATP at $1 \mathrm{~h}$ ). Samples were harvested $2 \mathrm{~h}$ after the addition of $\mathrm{Hg}(\mathrm{II})$ in both cases. In selecting the timing of ATP supplementation, we assumed that a substantial amount of endogenous ATP present in the lysate would decrease after $1 \mathrm{~h}$, and that the addition of exogenous ATP at that time point would increase $\mathrm{MeHg}$ production if $\mathrm{Hg}$ methylation is ATP dependent. The $1 \mathrm{~h}$ time point is within the initial, linear rate period of the $\mathrm{Hg}$ methylation progress curve (Fig. 2). Interestingly, MeHg production decreased significantly upon addition of exogenous ATP at concentrations of $2 \mathrm{mM}$ and $10 \mathrm{mM}$ $(P<0.05)$, by $38 \%$ and $95 \%$, respectively, compared to that of unamended samples (Fig. 5C). Addition of $2 \mathrm{mM} \mathrm{ATP}$ at $1 \mathrm{~h}$ did not significantly increase $\mathrm{MeHg}$ production. However, addition of $10 \mathrm{mM}$ ATP after $1 \mathrm{~h}$ significantly decreased the total amount of $\mathrm{MeHg}$ formed after $2 \mathrm{~h}$. The amount of $\mathrm{MeHg}$ produced after supplementation of $10 \mathrm{mM}$ ATP was about $56 \%$ of that formed under unamended conditions.

To rule out the possibility that the decrease in $\mathrm{MeHg}$ production in the presence of ATP may have arisen from the loss of $\mathrm{Hg}$ (II) through ATP-dependent reduction to $\mathrm{Hg}(0)$, we determined the concentration of THg in ND132 cell lysates after $2 \mathrm{~h}$. No significant loss in THg was observed in samples with or without added ATP (Fig. S4), indicating that the addition of ATP did not result in a loss of $\mathrm{Hg}(\mathrm{II})$ through reduction to $\mathrm{Hg}(0)$.

Genomic analysis of $\mathrm{Hg}$ methylators indicated the presence of a gene encoding a reductive activator of corrinoid proteins (RACo) in several Hg methylators (Table S1, Fig. S5). RACo harbors an ATP-binding site and has been shown to form a complex with CFeSP (34). Methylation of CFeSP occurs only in the Co(I) state, which can be oxidized sporadically to the inactive Co(II) state every 100-2,000 turnovers (35). RACo serves as the activator of inactive Co(II)-CFeSP to active Co(I)-CFeSP by coupling the hydrolysis of ATP to the reduction of $\mathrm{Co}(\mathrm{II})$ to $\mathrm{Co}(\mathrm{I})$ (36). In Moorella thermoacetica and Carboxydothermus hydrogenoformans, the gene encoding RACo is located in close proximity to the genes encoding enzymes of the reductive acetyl-CoA (Wood-Ljungdahl) pathway (35). Although D. desulfuricans ND132 lacks CFeSP and does not have a complete Wood-Ljungdahl pathway (20), we hypothesize that a RACo homolog, commonly present among many methylators, may serve a similar ATP-dependent corrinoid activation role for $\mathrm{HgcA}$.

We also evaluated the effect of the addition of the nonhydrolyzable ATP analog adenylyl-imidodiphosphate (AMP-PNP) on MeHg formation in ND132 cell lysates. AMPPNP was added at a concentration of $5 \mathrm{mM}$, an amount that is expected to compete with endogenous ATP for ATP hydrolysis sites of most ATPases (37). The addition of AMP-PNP resulted in a decrease of $\mathrm{MeHg}$ production by $33 \%(P<0.05)$ compared to that in the unamended control (Fig. 5D). This effect on MeHg production is similar to the decrease observed after addition of ATP. However, the mechanism by which both ATP and AMP-PNP decrease MeHg production is unclear.

\section{DISCUSSION}

Why bacteria and archaea methylate mercury remains a mystery, as methylation apparently does not impart these organisms with mercury resistance (3). Microbial Hg methylation has been the subject of investigation since the late 1960s $(11,38)$. The discovery of $h g c A B$ offered a first glimpse at the unique bioinorganic chemistry involved in the methylation of $\mathrm{Hg}$. In this study, we investigated the cellular $\mathrm{Hg}$ methylation mediated by HgcAB. We measured the contributions of enzymatic and nonenzymatic processes to $\mathrm{Hg}$ methylation in cell lysates of the anaerobic model $\mathrm{Hg}$ methylator D. desulfuricans ND132 and investigated the effect of various biochemical parameters and metabolites on $\mathrm{Hg}$ methylation. The mechanistic hypothesis of $\mathrm{Hg}$ methylation (Fig. 1B) was developed based on the sequences of $\mathrm{HgcA}$ and $\mathrm{HgcB}$, as well as early investigations of $\mathrm{Hg}$ methylation in D. desulfuricans LS (15-18).

As expected, methylation activity was detected in lysates of the WT, but not in lysates of the $\triangle h g c A B$ strain, confirming that $\mathrm{HgcA}$ and $\mathrm{HgcB}$ are essential for converting inorganic $\mathrm{Hg}$ (II) to MeHg (Fig. 2A). It should be noted that ND132 and other strains 
of sulfate-reducing bacteria have been reported to simultaneously methylate $\mathrm{Hg}$ (II) and demethylate $\mathrm{MeHg}(3,4)$. In our experiments with ND132 cell lysates, however, we did not observe demethylation of added $\mathrm{MeHg}$ over a period of several days (Fig. 2B). Therefore, we conclude that $\mathrm{Hg}$ methylation by $\mathrm{HgcAB}$ is irreversible and that there is no other mechanism independent of $\mathrm{HgcAB}$ for $\mathrm{MeHg}$ demethylation in experiments with ND132 cell lysates that may impact the $\mathrm{Hg}$ methylation rate parameters.

The rate of MeHg production in WT DN132 cell lysates was 6.5 times higher at pH 8.0 than at $\mathrm{pH} 4.0$ (Fig. 3A). This result is in contrast to the pH-rate profile for the nonenzymatic methylation of $\mathrm{Hg}(\mathrm{II})$ by methylcobalamin (Equation 1) in which the highest $\mathrm{Hg}$ methylation rate was observed at $\mathrm{pH} 4.5$, and decreased significantly at $\mathrm{pH}$ 6.0 and higher (13). In addition to $\mathrm{pH}$, the $\mathrm{Hg}$ methylation rates in WT cell lysates were also dependent on temperature. The highest rate of MeHg production in WT DN132 cell lysates was centered around $32^{\circ} \mathrm{C}$ with a fairly narrow optimum, decreasing by an order of magnitude at temperatures of $22^{\circ} \mathrm{C}$ and below or $40^{\circ} \mathrm{C}$ and above (Fig. 3B). The temperature dependence is consistent with the optimal growth temperature of $32^{\circ} \mathrm{C}$ for ND132 cultures and a lack of any substantial growth at $45^{\circ} \mathrm{C}$ and above (3). The observed $\mathrm{pH}$ and temperature dependencies suggest that $\mathrm{MeHg}$ is predominantly formed by an enzymatic process dependent on HgcAB under the experimental conditions.

At the lowest lysate concentration $(0.3 \mathrm{mg} / \mathrm{ml}$ protein), the initial rate of $\mathrm{MeHg}$ formation determined over a period of $2 \mathrm{~min}$ after $\mathrm{Hg}(\mathrm{II})$ addition was higher than the rate determined over a 2 -h period. However, the rate increased linearly with the concentration of the lysate in the 2-min experiments, while it increased exponentially with lysate concentration in the 2 -h experiments (Fig. $3 C$ and D). The linear increase in the 2-min experiments indicates that the rates of $\mathrm{MeHg}$ formation were limited only by the overall enzyme concentration. However, the exponential increase of Hg methylation rate at higher lysate concentrations in the 2-h experiments suggests that the rate is also dependent on the concentration of a secondary substrate present in the lysates, which may have been depleted over time. While this secondary substrate is currently unknown, our findings are consistent with previous studies with $D$. desulfuricans LS in which the rate of $\mathrm{MeHg}$ formation also increased exponentially with increasing cell lysate concentrations, suggesting that $\mathrm{Hg}$ methylation involves two or more components, such as a methyl donor, electron donor, and/or Hg(II) substrate (17). Nevertheless, $\mathrm{Hg}$ (II) substrate concentration dependence under the conditions tested in our experiments followed Michaelis-Menten kinetics (Fig. 4A). Although the estimated turnover numbers ( $k_{\text {cat' }} \sim 1 \times 10^{-5}$ to $1 \times 10^{-2} \mathrm{~s}^{-1}$ ) are very low compared to those of an average enzyme (Table 1 ), the low $K_{m}$ of $3.2 \mathrm{nM}$ yields catalytic efficiencies $\left(k_{\text {cat }} / K_{m^{\prime}} \sim 4 \times 10^{3}\right.$ to $4 \times 10^{6} \mathrm{M}^{-1} \cdot \mathrm{s}^{-1}$ ) that fall within reasonable ranges (39).

The chemical speciation of $\mathrm{Hg}(\mathrm{II})$ is a critical factor that may impact apparent methylation rates due to the high affinity of $\mathrm{Hg}(\mathrm{II})$ for biological thiolates (SR ${ }^{-}$) with stability constants ( $\log \beta$ ) of up to 45 for $\mathrm{Hg}(\mathrm{II})$-bis-thiolate $\left[\mathrm{Hg}(\mathrm{SR})_{2}\right]$ complexes (40). Intracellular thiolates comprise thiol functional groups on proteins (i.e., cysteine) and small molecular thiols. The concentration of thiols in cells can range from 0.1 to $10 \mathrm{mM}$ (40), which is approximately 3 orders of magnitude higher than the $\mathrm{Hg}$ (II) concentrations used for methylation assays $(0.5 \mathrm{nM}$ to $60 \mathrm{nM})$. Therefore, $\mathrm{Hg}$ (II)-thiolate complexes are expected to be the dominant species in cells, as thiolates tend to outcompete any other ligands under these conditions. We evaluated the effect of thiolate levels by comparing methylation rates in the presence of 2 to $10 \mathrm{mM}$ DTT. Our data show that high thiolate/Hg(II) ratios did not impact $\mathrm{Hg}$ methylation rates significantly (Fig. S2). Consequently, the concentration of DTT was maintained at $2 \mathrm{mM}$ in all cell lysate experiments to keep $\mathrm{Hg}(\mathrm{II})$ speciation identical between experiments. It should be noted that although the thermodynamic stability of $\mathrm{Hg}(\mathrm{SR})_{2}$ species is extremely high, ligand exchange of such complexes with other free thiolates is rapid (41). Therefore, the low $K_{m}$ and quantitative conversion of $\mathrm{Hg}(\mathrm{II})$ to $\mathrm{MeHg}$ at high thiolate/ $\mathrm{Hg}$ (II) ratios (Fig. 4B) are remarkable and suggest the existence of an active site that may harbor thiolate ligands to bind $\mathrm{Hg}(\mathrm{II})$ with high affinity, possibly involving a ligand 
exchange mechanism, similar to mechanisms previously described for MerA and MerB $(42,43)$. A series of conserved cysteines identified in sequences of $\mathrm{HgcB}$ (C94, C95, and C73) may facilitate such ligand exchange processes. Indeed, site-directed mutagenesis experiments in ND132 showed that a C73A mutation eliminates $\mathrm{Hg}$ methylation in vivo, but only one of the two C-terminal cysteines (C94 or C95) is essential for activity (21).

Based on the hypothesized roles for $\mathrm{HgcA}$ and $\mathrm{HgcB}$ (Fig. 1B), in addition to a $\mathrm{Hg}$ (II) substrate, $\mathrm{Hg}$ methylation requires both a source of electrons to regenerate the $\mathrm{Co}(\mathrm{I})$ state of the corrinoid cofactor and a methyl donor. Although the source of electrons is unknown, $\mathrm{HgcB}$ likely assumes a key role in shuttling electrons from an unidentified electron donor to the corrinoid cofactor of HgcA. If the intracellular molar ratio of $\mathrm{HgcA}$ to $\mathrm{HgcB}$ remains constant, the generation of electrons may become rate limiting as it depends on active metabolic processes, which are expected to decrease in the cell lysates over time. Furthermore, the immediate methyl donor to HgcA remains unknown, as supplementation of $\mathrm{CH}_{3}-\mathrm{H}_{4}$ folate did not result in an increased rate of $\mathrm{Hg}$ methylation over a period of $2 \mathrm{~h}$ (Fig. 5B).

If MeHg formation is dependent on energy derived from ATP hydrolysis, such as the ATP-dependent corrinoid activation by a reductive activator (RACo), adding ATP or a nonhydrolyzable ATP would be expected to affect MeHg production. Our experiments showed that supplementation of ATP leads to a substantial decrease in $\mathrm{Hg}$ methylation activity in cell lysates (Fig. 5C). A similar decrease in $\mathrm{Hg}$ methylation was observed with the competitive nonhydrolyzable analog AMP-PNP (Fig. 5D). Thus, we could not confirm the hypothesis that reductive activation by RACo or a similar ATP-dependent activator is essential for $\mathrm{Hg}$ methylation. Alternatively, ATP may affect $\mathrm{Hg}$ speciation or impact other, yet to be identified, cellular components related to $\mathrm{Hg}$ methylation.

Several key observations in this study are consistent with results obtained from studies with $D$. desulfuricans LS. The majority (>95\%) of cellular Co in $D$. desulfuricans LS was reported to be associated with macromolecules (16). In ND132 cell lysates, no nonenzymatic $\mathrm{Hg}$ methylation was observed and, in the $\triangle$ hgcAB mutant, $\mathrm{Hg}$ methylation was negligible, indicating that $\mathrm{HgcAB}$ is indeed responsible for all $\mathrm{Hg}$ methylation. A 40-kDa protein, being the only major Co-containing protein in D. desulfuricans LS (17), agrees with the molecular mass of ND132 HgcA (36.7 kDa without its corrinoid cofactor) or with a HgcAB complex (1:1 molar ratio; $\sim 49 \mathrm{kDa})$, although it is not known whether $\mathrm{HgcA}$ and $\mathrm{HgcB}$ form a stable complex.

However, there are several differences between the experimental conditions used in the present study and those performed previously with $D$. desulfuricans LS. While the typical concentration of $\mathrm{Hg}(\mathrm{II})$ in our experiments was $30 \mathrm{nM}$, which is similar to levels used for methylation experiments with whole cells (25), experiments with D. desulfuricans LS were conducted at $\mathrm{Hg}$ (II) levels in the $\mathrm{mM}$ range $(0.5$ to $8 \mathrm{mM})$ (17). $\mathrm{Hg}$ toxicity to ND132 cells was apparent through decreased cell density at $\mathrm{Hg}$ concentrations above $\sim 5 \mu \mathrm{M}$ (3). Detection limits for the analysis of $\mathrm{MeHg}$ by inductively coupled plasma mass spectrometry (ICP-MS) following the current standard Environmental Protection Agency (EPA) methods are in the low pM range (44). The vastly improved detection limits for MeHg enable our studies at significantly lower Hg levels, which are more physiologically relevant and dramatically reduce potential impacts of $\mathrm{Hg}$ toxicity to cellular proteins. These advances also allowed us to evaluate $\mathrm{Hg}$ methylation kinetics in lysates without supplementing essential metabolites. For example, no Hg methylation was observed with $D$. desulfuricans LS cell extracts unless $10 \mathrm{mM}$ pyruvate and $16.8 \mu \mathrm{M} \mathrm{CH} \mathrm{CH}_{3}-\mathrm{H}_{4}$ folate were added (18). Under our experimental conditions, we observed no effect on $\mathrm{Hg}$ methylation activity in ND132 cell lysates of adding an exogenous methyl donor $\left(\mathrm{CH}_{3}-\mathrm{H}_{4}\right.$ folate) or electron source (pyruvate). These differences in the experimental design are reflected in differences between the $V_{\text {max }}$ and $K_{m}$ values previously determined for $D$. desulfuricans LS $\left(V_{\max }=0.728 \mathrm{nmol} \mathrm{m^{-1 }} \cdot \mathrm{mg}\right.$ protein ${ }^{-1}$ and $\left.K_{m}=0.872 \mathrm{mM}\right)$ and those described here $\left(V_{\max }=19.7 \mathrm{fmol} \cdot \mathrm{min}^{-1}\right.$. mg total protein ${ }^{-1}$ and $\left.K_{m}=3.2 \mathrm{nM}\right)$. Differences in the inhibition of methylation activity by ambient oxygen (45\% for D. desulfuricans LS [17], 95\% in this study) suggest that nonenzymatic methylation may have been more prominent in studies with $D$. 
desulfuricans LS and may have contributed to overall MeHg production. Here, we showed that essentially all of the MeHg formed in ND132 is a product of enzymatic activity mediated by $\mathrm{HgcAB}$.

Inhibition of $\mathrm{Hg}$ methylation by oxygen is consistent with the proposed HgcABmediated turnover cycle (Fig. 1B). Exposure of cell lysates to ambient oxygen could inactivate either FeS-containing $\mathrm{HgcB}$ or corrinoid-containing $\mathrm{HgcA}$ or oxidize the active $\mathrm{Co}(\mathrm{I})$-corrinoid to $\mathrm{Co}$ (II) or $\mathrm{Co}(\mathrm{III})$. As a consequence, in the presence of oxygen, HgcA would not be able to accept a methyl group, thus interrupting the turnover cycle. Nevertheless, further studies to identify the chemistry of the specific corrinoid cofactor and direct evidence for its participation in $\mathrm{Hg}$ methylation are needed.

We speculate that the fraction of $\mathrm{HgcA}$ is equivalent to approximately $0.0004 \%$ of the total protein concentration in cell lysates (see supplemental material), which would correspond to approximately 1 in 220,000 proteins in the cell lysate. Such low abundance would explain difficulties in identifying $\mathrm{HgcA}$ protein fragments and low transcript levels in previously published studies $(20,27,28)$. The calculated kinetic parameters resulting from this $\mathrm{HgcA}$ abundance estimate are $k_{\text {cat }}=3 \times 10^{-3}$ $\mathrm{s}^{-1}$, and $k_{\text {cat }} / K_{m}=9 \times 10^{5} \mathrm{M}^{-1} \cdot \mathrm{s}^{-1}$. Consequently, we speculate that the specific activity of $\mathrm{HgcA}$ is close to $4 \mathrm{nmol} \cdot \mathrm{min}^{-1} \cdot \mathrm{mg}^{-1} \mathrm{HgcA}$. Comparing the current estimated rate constant for the HgcAB-mediated enzymatic $\mathrm{Hg}$ methylation to previously published nonenzymatic rate constants for methylcobalamin, the enzymatic reaction is approximately 2,500 times faster at $\mathrm{pH} 7.0$ than the nonenzymatic reaction, which is fastest at $\mathrm{pH} 4.5(12,13)$. Although the cofactor-replete expression and purification of $\mathrm{HgcA}$ and $\mathrm{HgcB}$ presents significant challenges, studies with purified $\mathrm{HgcA}$ and $\mathrm{HgcB}$ will be essential to validate the postulated kinetic parameters.

In conclusion, we demonstrate that cell lysates containing $\mathrm{HgcA}$ and $\mathrm{HgcB}$ exhibit $\mathrm{Hg}$ methylation activity even at subnanomolar $\mathrm{Hg}$ (II) concentrations, which is remarkable considering $\mathrm{Hg}(\mathrm{II})$ is known to form thermodynamically stable complexes with the abundant pool of cellular thiols present in cells. Future studies aimed at characterizing the molecular structures and functions of $\mathrm{HgcA}$ and $\mathrm{HgcB}$ are essential to delineate the interplay between methyl donor, electron donor, and the $\mathrm{Hg}(\mathrm{II})$ substrate in cellular $\mathrm{Hg}$ methylation. Taking into consideration that deletion of hgcAB does not significantly alter the growth of $\mathrm{Hg}$ methylators, understanding the cellular biochemistry of $\mathrm{Hg}$ methylation could help inform strategies to limit $\mathrm{MeHg}$ formation in $\mathrm{Hg}$-methylating bacteria and archaea and thus curtail the formation of this potent neurotoxin in the environment.

\section{MATERIALS AND METHODS}

Strains and culture conditions. Desulfovibrio desulfuricans ND132 cells (wild-type [WT] or $\triangle h g c A B$ mutant) were grown in modified minimal organic yeast medium containing $40 \mathrm{mM}$ fumarate, $40 \mathrm{mM}$ pyruvate, and $1.2 \mathrm{mM}$ thioglycolate and $1 \mathrm{mM}$ cysteine $\mathrm{HCl}$ as reducing agents for 3 days (optical density at $\left.600 \mathrm{~nm}\left[\mathrm{OD}_{600}\right]=0.3\right)$ at $32^{\circ} \mathrm{C}$ under strictly anaerobic conditions $\left(<0.6 \mathrm{ppm} \mathrm{O}_{2}\right)$ in 2-liter medium bottles capped with butyl rubber stoppers (21). For the preparation of ND132 cell lysates, all of the following steps were carried out under strictly anaerobic conditions inside a LabMaster Pro glove box (MBraun, Stratham, $\mathrm{NH}$ ) under an $\mathrm{N}_{2}$ atmosphere maintained below $0.6 \mathrm{ppm} \mathrm{O}_{2}$. The cultures were harvested at $4^{\circ} \mathrm{C}$ by centrifugation for $20 \mathrm{~min}$ at 7,500 $\times \mathrm{g}$ in centrifuge bottles with sealing closures. Pellets were washed 2 times with deoxygenated phosphate-buffered saline (PBS; pH 7.0). Cell pellets were resuspended in cold resuspension solution (Pierce EDTA-free protease inhibitor [Thermo Fisher Scientific, Waltham, MA] Benzonase nuclease [MilliporeSigma, St. Louis, MO], and 2 mM dithiothreitol [DTT] in PBS [pH 7.0]) and disrupted on ice by four cycles of sonication (50 sec, 70\% power) with a Sonic Dismembrator 250 (Thermo Fisher Scientific, Waltham, MA) under minimal light to prevent photolytic degradation of methylcorrinoids. Unlysed cells were removed by centrifugation at 30,000 $\times g$ for $1 \mathrm{~h}$ at $4^{\circ} \mathrm{C}$. Removal of unlysed cells was confirmed by microscopic examination with an Axioscope 2 (Carl Zeiss Microscopy LLC, Thornwood, NY). Total protein concentration of cell lysates was determined by the Bradford method with bovine serum albumin (MilliporeSigma, St. Louis, MO) as the standard, and the lysates were stored in aliquots at $-80^{\circ} \mathrm{C}$ in amber glass vials capped with Teflon-lined silicone stoppers and sealed. Cell lysates were used within 2 weeks of preparation.

Methylation assays. Methylation assays were performed under strictly anaerobic conditions in the dark at $32^{\circ} \mathrm{C}$ inside an anaerobic glove box at a total protein concentration of $1.5 \mathrm{mg} / \mathrm{ml}$ for $2 \mathrm{~h}$ (standard conditions), unless otherwise specified. To avoid any potential variability that may result from differences in the thiolate concentrations in the cell lysates, the concentration of DTT was kept constant at $2 \mathrm{mM}$ for all experiments. Cell lysates of ND132 WT and $\triangle h g c A B$ were equilibrated under the desired experimental 
conditions for 2 min before adding aliquots of a freshly prepared $1.5 \mu \mathrm{M}(300 \mathrm{ppb}) \mathrm{HgCl}_{2}$ stock solution to a final concentration of $30 \mathrm{nM}(6 \mathrm{ppb})$, unless otherwise specified. The reactions were stopped at the desired time points by adding $0.5 \%$ (vol/vol) trace-metal grade $\mathrm{H}_{2} \mathrm{SO}_{4}$ (Thermo Fisher Scientific, Waltham, $\mathrm{MA}$ ), and the samples were moved immediately to a $-20^{\circ} \mathrm{C}$ freezer and stored until $\mathrm{MeHg}$ analysis. All experiments were performed in duplicate. The reaction buffer, PBS ( $\mathrm{pH} 7.0$; without cell lysates) and $\triangle h g c A B$ cell lysates were used as controls. Samples were processed similarly for total $\mathrm{Hg}$ (THg) analysis. Experiment-specific variations used, while keeping all other parameters constant, were as follows. For the time dependence experiments, aliquots were removed from the reaction mixture before the addition of $\mathrm{Hg}$ (II) $(\mathrm{O} \mathrm{h})$, and following the addition of $\mathrm{Hg}(\mathrm{II})$ at $2 \mathrm{~min}, 30 \mathrm{~min}, 2$, 4, 24, 48, 72, and $92 \mathrm{~h}$. For the $\mathrm{pH}$ dependence experiments, the cell lysates were diluted in PBS buffer and solutions were adjusted to $\mathrm{pH}$ values of 4.0, 5.0, 6.0, 7.0, 8.0, and 9.0, respectively. For the temperature dependence experiments, the samples were preequilibrated before the addition of $\mathrm{Hg}(\mathrm{II})$ for $5 \mathrm{~min}$ at the desired temperatures, $4^{\circ} \mathrm{C}$, room temperature $\left(24^{\circ} \mathrm{C}\right), 32,40$, and $50^{\circ} \mathrm{Crespectively,} \mathrm{and,} \mathrm{following} \mathrm{the} \mathrm{addition} \mathrm{of} \mathrm{Hg}(\mathrm{II})$, the samples were incubated for $2 \mathrm{~h}$. For the protein concentration dependence experiments, the cell lysates were diluted to final protein concentrations of $0.3,0.6,1.3$, and $2.6 \mathrm{mg} / \mathrm{ml}$, respectively. For the substrate concentration dependence experiments, cell lysates were spiked with $\mathrm{Hg}$ (II) to final concentrations of 0.5 , $1,5,10,15,50$ and $60 \mathrm{nM}$ with stock solutions of $50 \mathrm{nM}, 0.5$ and $1.5 \mu \mathrm{M}$. The effects of pyruvate and $\mathrm{CH}_{3}-\mathrm{H}_{4}$ folate were tested by adding a freshly prepared sodium pyruvate stock solution (500 mM) to a final pyruvate concentration of $10 \mathrm{mM}$ and a freshly prepared $10 \mathrm{mg} / \mathrm{ml}$ stock solution of $\mathrm{CH}_{3}-\mathrm{H}_{4}$ folate (MilliporeSigma, St. Louis, MO) to a final concentration of $16.8 \mu \mathrm{M}$. The samples were equilibrated with pyruvate and $\mathrm{CH}_{3}-\mathrm{H}_{4}$ folate for 2 min before the addition of $\mathrm{Hg}(\mathrm{II})$. To test the oxygen sensitivity, sets of WT and $\triangle h g c A B$ cell lysates were incubated at standard conditions inside the glove box $\left(<0.6 \mathrm{ppm} \mathrm{O}_{2}\right)$, and other sets were preequilibrated outside the glove box (at ambient $\mathrm{O}_{2}$ ) for 2 min before the addition of $\mathrm{Hg}(\mathrm{II})$. The incubation was continued for $2 \mathrm{~h}$ under the same conditions after the addition of $\mathrm{Hg}$ (II). All other experimental parameters and procedures were as described above.

The effect of ATP was tested by adding a freshly prepared stock solution of ATP disodium salt (MilliporeSigma, St. Louis, MO) to a set of vials before the addition of $\mathrm{Hg}$ (II) (ATP at $0 \mathrm{~h}$ ) and $1 \mathrm{~h}$ after the addition of $\mathrm{Hg}$ (II) (ATP at $1 \mathrm{~h}$ ) to achieve final ATP concentrations of $2 \mathrm{mM}$ and $10 \mathrm{mM}$. The reaction was stopped at $2 \mathrm{~h}$, as described previously. To test the effect of a nonhydrolyzable ATP analog, a freshly prepared stock solution of adenosine $5^{\prime}-(\beta, \gamma$-imido)triphosphate lithium salt hydrate (MilliporeSigma, St. Louis, MO) was added to cell lysates to a final concentration of $5 \mathrm{mM}$ and incubated for 5 min before initiating the reaction by addition of $\mathrm{Hg}(\mathrm{II})$.

Demethylation assays. Demethylation potentials were measured in the cell lysates of WT and $\triangle h g c A B$ ND132; the samples were processed under standard conditions described above, except that $5 \mathrm{nM} \mathrm{MeHg}$ was used as the substrate instead of $\mathrm{Hg}(\mathrm{II})$. A $250 \mathrm{nM} \mathrm{MeHg}$ working stock solution was freshly prepared from a 1 ppm methylmercury standard solution (Brooks Rand Instruments, Seattle, WA).

Total mercury analysis. All samples were treated with $5 \%$ (vol/vol) BrCl overnight, followed by 5 -min incubation with $30 \%$ (wt/vol) $\mathrm{NH}_{2} \mathrm{OH} \mathrm{HCl}$ before the total mercury ( $\mathrm{THg}$ ) analysis. $\mathrm{THg}$ was analyzed by reduction with $0.8 \%$ (wt/vol) stannous chloride $\left(\mathrm{SnCl}_{2}\right)$ on an $\mathrm{RA}-915+$ mercury analyzer (Ohio Lumex, USA). An aliquot of $\mathrm{Hg}$-containing sample was added to an excess of $0.8 \%$ (wt/vol) $\mathrm{SnCl}_{2}$ and purged with ultrahigh-purity $\mathrm{N}_{2}$. The emerging $\mathrm{Hg}(0)$ was quantified by a cold vapor atomic absorption spectroscopy (CV-AAS) Zeeman effect Hg analyzer (Lumex RA-915+; Ohio Lumex Company, Inc. Twinsburg, OH), which was calibrated with a set of $\mathrm{Hg}$ standards (Brooks Rand Instruments, Seattle, WA).

Methylmercury analysis. All samples were processed using a nonaqueous extraction method (45) followed by a modified version of EPA method 1630, described previously (44). Briefly, Me $\mathrm{MeOHg}^{20}$ was added to all the samples as an internal standard, methylmercury ( $\mathrm{MeHg}$ ) was then extracted with an acidic $\mathrm{KBr}$ solution, followed by extraction of $\mathrm{MeHg}$ with $\mathrm{CH}_{2} \mathrm{Cl}_{2}$. After phase separation, $\mathrm{CH}_{2} \mathrm{Cl}_{2}$ was volatilized completely to release $\mathrm{MeHg}$ into a pure aqueous phase. $\mathrm{MeHg}$ samples were further processed by distillation, ethylation, and trapping on a Tenax column via $\mathrm{N}_{2}$-purging. Following thermal desorption and separation by gas chromatography, MeHg was detected by ICP-MS. The recovery of spiked MeHg standards was $100 \% \pm 10 \%$, and the detection limit was about $3 \times 10^{-5} \mathrm{nM} \mathrm{MeHg}$.

Statistical analysis. GraphPad Prism (GraphPad Software, La Jolla, CA) and the R software environment for statistical computing and graphics (https://www.r-project.org/) were used to analyze and plot the data.

\section{SUPPLEMENTAL MATERIAL}

Supplemental material for this article may be found at https://doi.org/10.1128/AEM .00438-19.

SUPPLEMENTAL FILE 1, PDF file, 0.7 MB.

\section{ACKNOWLEDGMENTS}

We thank Xiangping Yin and Linduo Zhao at Oak Ridge National Laboratory (ORNL) for technical assistance in mercury and methylmercury analyses.

This research was sponsored by the Office of Biological and Environmental Research, Office of Science, U.S. Department of Energy (DOE), as part of the Critical Interfaces Science Focus Area at Oak Ridge National Laboratory, which is managed by UT-Battelle, LLC, for the DOE under contract DE-AC05-00OR22725. The manuscript was authored by 
UT-Battelle, LLC, under contract no. DE-AC05-00OR22725 with the U.S. Department of Energy.

The Department of Energy will provide public access to these results of federally sponsored research in accordance with the DOE Public Access Plan (https://www .energy.gov/downloads/doe-public-access-plan).

We declare that we have no conflicts of interest regarding the contents of this article.

S.S.D., J.D.W., S.W.R., J.M.P., and A.J. designed the research. S.S.D. and A.J. performed the experiments and analyses. S.S.D., K.W.R., J.M.P., J.D.W., S.W.R., and A.J. wrote the paper.

\section{REFERENCES}

1. United Nations Environment Programme. 2013. Global Mercury Assessment 2013: sources, emissions, releases, and environmental transport. UNEP Chemicals Branch, Geneva, Switzerland.

2. Castoldi AF, Coccini T, Manzo L. 2003. Neurotoxic and molecular effects of methylmercury in humans. Rev Environ Health 18:19-31.

3. Gilmour CC, Elias DA, Kucken AM, Brown SD, Palumbo AV, Schadt CW, Wall JD. 2011. Sulfate-reducing bacterium Desulfovibrio desulfuricans ND132 as a model for understanding bacterial mercury methylation. Appl Environ Microbiol 77:3938-3951. https://doi.org/10.1128/AEM .02993-10.

4. Bridou R, Monperrus M, Gonzalez PR, Guyoneaud R, Amouroux D. 2011. Simultaneous determination of mercury methylation and demethylation capacities of various sulfate-reducing bacteria using species-specific isotopic tracers. Environ Toxicol Chem 30:337-344. https://doi.org/10 .1002/etc.395.

5. Ranchou-Peyruse M, Monperrus M, Bridou R, Duran R, Amouroux D, Salvado JC, Guyoneaud R. 2009. Overview of mercury methylation capacities among anaerobic bacteria including representatives of the sulphate-reducers: implications for environmental studies. Geomicrobiol J 26:1-8. https://doi.org/10.1080/01490450802599227.

6. Gilmour CC, Podar M, Bullock AL, Graham AM, Brown SD, Somenahally AC, Johs A, Hurt RA, Jr, Bailey KL, Elias DA. 2013. Mercury methylation by novel microorganisms from new environments. Environ Sci Technol 47:11810-11820. https://doi.org/10.1021/es403075t.

7. Graham AM, Bullock AL, Maizel AC, Elias DA, Gilmour CC. 2012. Detailed assessment of the kinetics of $\mathrm{Hg}$-cell association, $\mathrm{Hg}$ methylation, and methylmercury degradation in several Desulfovibrio species. Appl Environ Microbiol 78:7337-7346. https://doi.org/10.1128/AEM.01792-12.

8. Heyes A, Mason RP, Kim EH, Sunderland E. 2006. Mercury methylation in estuaries: insights from using measuring rates using stable mercury isotopes. Mar Chem 102:134-147. https://doi.org/10.1016/j.marchem.2005.09 .018 .

9. Zhao L, Chen H, Lu X, Lin H, Christensen GA, Pierce EM, Gu B. 2017. Contrasting effects of dissolved organic matter on mercury methylation by Geobacter sulfurreducens PCA and Desulfovibrio desulfuricans ND132. Environ Sci Technol 51:10468-10475. https://doi.org/10.1021/acs.est.7b02518.

10. Schaefer JK, Morel FMM. 2009. High methylation rates of mercury bound to cysteine by Geobacter sulfurreducens. Nat Geosci 2:123-126. https:// doi.org/10.1038/ngeo412.

11. Wood JM, Kennedy FS, Rosen CG. 1968. Synthesis of methyl-mercury compounds by extracts of a methanogenic bacterium. Nature 220:173. https://doi.org/10.1038/220173a0.

12. Bertilsson L, Neujahr HY. 1971. Methylation of mercury compounds by methylcobalamin. Biochemistry 10:2805-2808.

13. DeSimone RE, Penley MW, Charbonneau L, Smith SG, Wood JM, Hill HA, Pratt JM, Ridsdale S, Williams RJ. 1973. The kinetics and mechanism of cobalamin-dependent methyl and ethyl transfer to mercuric ion. Biochim Biophys Acta 304:851-863. https://doi.org/10.1016/0304-4165(73) 90232-8.

14. Compeau GC, Bartha R. 1985. Sulfate-reducing bacteria: principal methylators of mercury in anoxic estuarine sediment. Appl Environ Microbiol 50:498-502.

15. Berman M, Chase T, Bartha R. 1990. Carbon flow in mercury biomethylation by Desulfovibrio desulfuricans. Appl Environ Microbiol 56:298-300.

16. Choi SC, Bartha R. 1993. Cobalamin-mediated mercury methylation by Desulfovibrio desulfuricans LS. Appl Environ Microbiol 59:290-295.

17. Choi SC, Chase T, Jr, Bartha R. 1994. Enzymatic catalysis of mercury methylation by Desulfovibrio desulfuricans LS. Appl Environ Microbiol 60:1342-1346.

18. Choi SC, Chase T, Jr, Bartha R. 1994. Metabolic pathways leading to mercury methylation in Desulfovibrio desulfuricans LS. Appl Environ Microbiol 60:4072-4077.

19. Ekstrom EB, Morel FM, Benoit JM. 2003. Mercury methylation independent of the acetyl-coenzyme A pathway in sulfate-reducing bacteria. Appl Environ Microbiol 69:5414-5422. https://doi.org/10.1128/AEM.69.9 .5414-5422.2003.

20. Parks JM, Johs A, Podar M, Bridou R, Hurt RA, Jr, Smith SD, Tomanicek SJ, Qian Y, Brown SD, Brandt CC, Palumbo AV, Smith JC, Wall JD, Elias DA, Liang L. 2013. The genetic basis for bacterial mercury methylation. Science 339:1332-1335. https://doi.org/10.1126/science.1230667.

21. Smith SD, Bridou R, Johs A, Parks JM, Elias DA, Hurt RA, Jr, Brown SD, Podar M, Wall JD. 2015. Site-directed mutagenesis of HgcA and $\mathrm{HgcB}$ reveals amino acid residues important for mercury methylation. Appl Environ Microbiol 81:3205-3217. https://doi.org/10.1128/AEM.00217-15.

22. Zhou J, Riccardi D, Beste A, Smith JC, Parks JM. 2014. Mercury methylation by $\mathrm{HgcA}$ : theory supports carbanion transfer to $\mathrm{Hg}$ (II). Inorg Chem 53:772-777. https://doi.org/10.1021/ic401992y.

23. Demissie TB, Garabato BD, Ruud K, Kozlowski PM. 2016. Mercury methylation by cobalt corrinoids: relativistic effects dictate the reaction mechanism. Angew Chem Int Ed Engl 55:11503-11506. https://doi.org/10 .1002/anie.201606001.

24. Schaefer JK, Rocks SS, Zheng W, Liang L, Gu B, Morel FMM. 2011. Active transport, substrate specificity, and methylation of $\mathrm{Hg}(\mathrm{II})$ in anaerobic bacteria. Proc Natl Acad Sci U S A 108:8714-8719. https://doi.org/10 .1073/pnas.1105781108.

25. Liu YR, Lu X, Zhao LD, An J, He JZ, Pierce EM, Johs A, Gu BH. 2016. Effects of cellular sorption on mercury bioavailability and methylmercury production by Desulfovibrio desulfuricans ND132. Environ Sci Technol 50: 13335-13341. https://doi.org/10.1021/acs.est.6b04041.

26. Gilmour CC, Bullock AL, McBurney A, Podar M, Elias DA. 2018. Robust mercury methylation across diverse methanogenic archaea. mBio 9:e02403-17. https://doi.org/10.1128/mBio.02403-17.

27. Qian C, Chen HM, Johs A, Lu X, An J, Pierce EM, Parks JM, Elias DA Hettich RL, Gu BH. 2018. Quantitative proteomic analysis of biological processes and responses of the bacterium Desulfovibrio desulfuricans ND132 upon deletion of its mercury methylation genes. Proteomics 18:e1700479. https://doi.org/10.1002/pmic.201700479.

28. Qian C, Johs A, Chen H, Mann BF, Lu X, Abraham PE, Hettich RL, Gu B. 2016. Global proteome response to deletion of genes related to mercury methylation and dissimilatory metal reduction reveals changes in respiratory metabolism in Geobacter sulfurreducens PCA. J Proteome Res 15:3540-3549. https://doi.org/10.1021/acs.jproteome.6b00263.

29. Lienhard GE. 1973. Enzymatic catalysis and transition-state theory. Science 180:149-154. https://doi.org/10.1126/science.180.4082.149.

30. Eyring H. 1935. The activated complex in chemical reactions. J Chem Phys 3:107-115. https://doi.org/10.1063/1.1749604.

31. Schumacher W, Holliger C, Zehnder AJ, Hagen WR. 1997. Redox chemistry of cobalamin and iron-sulfur cofactors in the tetrachloroethene reductase of Dehalobacter restrictus. FEBS Lett 409:421-425. https://doi .org/10.1016/S0014-5793(97)00520-6.

32. Lexa D, Saveant JM. 1983. The electrochemistry of vitamin $B_{12}$. Acc Chem Res 16:235-243. https://doi.org/10.1021/ar00091a001.

33. Yaginuma H, Kawai S, Tabata KV, Tomiyama K, Kakizuka A, Komatsuzaki T, Noji H, Imamura H. 2014. Diversity in ATP concentrations in a single 
bacterial cell population revealed by quantitative single-cell imaging. Sci Rep 4:6522. https://doi.org/10.1038/srep06522.

34. Meister $\mathrm{W}$, Hennig $\mathrm{SE}$, Jeoung $\mathrm{JH}$, Lendzian $\mathrm{F}$, Dobbek $\mathrm{H}$, Hildebrandt $\mathrm{P}$. 2012. Complex formation with the activator RACo affects the corrinoid structure of CoFeSP. Biochemistry 51:7040-7042. https://doi.org/10.1021/ bi300795n.

35. Ragsdale SW, Pierce E. 2008. Acetogenesis and the Wood-Ljungdahl pathway of $\mathrm{CO}_{2}$ fixation. Biochim Biophys Acta 1784:1873-1898. https:// doi.org/10.1016/j.bbapap.2008.08.012.

36. Hennig SE, Jeoung JH, Goetzl S, Dobbek H. 2012. Redox-dependent complex formation by an ATP-dependent activator of the corrinoid/ironsulfur protein. Proc Natl Acad Sci U S A 109:5235-5240. https://doi.org/ 10.1073/pnas.1117126109.

37. Brady ST. 1985. A novel brain ATPase with properties expected for the fast axonal transport motor. Nature 317:73-75. https://doi.org/10.1038/ $317073 a 0$.

38. Jensen S, JernelÖV A. 1969. Biological methylation of mercury in aquatic organisms. Nature 223:753. https://doi.org/10.1038/223753a0.

39. Bar-Even A, Noor E, Savir Y, Liebermeister W, Davidi D, Tawfik DS, Milo R. 2011. The moderately efficient enzyme: evolutionary and physicochemical trends shaping enzyme parameters. Biochemistry 50:4402-4410. https://doi.org/10.1021/bi2002289.

40. Cardiano P, Falcone G, Foti C, Sammartano S. 2011. Sequestration of
$\mathrm{Hg}^{2+}$ by some biologically important thiols. J Chem Eng Data 56: 4741-4750. https://doi.org/10.1021/je200735r.

41. Cheesman BV, Arnold AP, Rabenstein DL. 1988. Nuclear magnetic resonance studies of the solution chemistry of metal complexes. 25. $\mathrm{Hg}(\text { thiol })_{3}$ complexes and $\mathrm{Hg}(\mathrm{II})$-thiol ligand exchange kinetics. J Am Chem Soc 110:6359-6364. https://doi.org/10.1021/ja00227a014.

42. Benison GC, Di Lello P, Shokes JE, Cosper NJ, Scott RA, Legault P, Omichinski JG. 2004. A stable mercury-containing complex of the organomercurial lyase MerB: catalysis, product release, and direct transfer to MerA. Biochemistry 43:8333-8345. https://doi.org/10.1021/bi049662h.

43. Lian $P$, Guo HB, Riccardi D, Dong AP, Parks JM, Xu Q, Pai EF, Miller SM, Wei DQ, Smith JC, Guo H. 2014. X-ray structure of a $\mathrm{Hg}^{2+}$ complex of mercuric reductase (MerA) and quantum mechanical/molecular mechanical study of $\mathrm{Hg}^{2+}$ transfer between the C-terminal and buried catalytic site cysteine pairs. Biochemistry 53:7211-7222. https://doi.org/ 10.1021/bi500608u.

44. U.S. Environmental Protection Agency. 1998. Method 1630: methyl mercury in water by distillation, aqueous ethylation, purge and trap, and CVAFS. U.S. Environmental Protection Agency, Washington, DC.

45. Bloom NS, Colman JA, Barber L. 1997. Artifact formation of methyl mercury during aqueous distillation and alternative techniques for the extraction of methyl mercury from environmental samples. Fresen J Anal Chem 358:371-377. https://doi.org/10.1007/s002160050432. 